\title{
EFFECT OF TEMPERATURE AND PRECIPITATION ON STEM BIOMASS AND COMPOSITION OF WHITE BIRCH (BETULA PLATYPHYLLA) IN DAXING'ANLING MOUNTAINS INNER MONGOLIA, CHINA
}

\author{
KHAN, D..$^{1 *}$ - Din, E. U. ${ }^{7}$ - MuneER, M. A. ${ }^{2}$ - HAYAT, M. ${ }^{3}$-Khan, T. U. ${ }^{4}-$ AsIF, M. ${ }^{1}-$ SHAH, \\ S. ${ }^{1}-$ UdDIN, S. ${ }^{5}-$ MUNIR, M. Z. ${ }^{5}-$ ZAIB-UN-NISA ${ }^{5,6}-$ YIHONG, Z. ${ }^{1}-$ HUANG, H. ${ }^{1 *}-$ GAO, L. ${ }^{1 *}$ \\ ${ }^{1}$ College of Forestry, Beijing Forestry University \\ No 35 Qinghua East Road, Haidian District, 100083 Beijing, China \\ ${ }^{2}$ College of Grassland Science, Beijing Forestry University \\ No 35 Qinghua East Road, Haidian District, 100083 Beijing, China \\ ${ }^{3}$ College of Soil and Water Conservation, Beijing Forestry University \\ No 35 Qinghua East Road, Haidian District, 100083 Beijing, China \\ ${ }^{4}$ College of Nature Conservation, Beijing Forestry University \\ No 35 Qinghua East Road, Haidian District, 100083 Beijing, China \\ ${ }^{5}$ School of Biological Sciences and Technology, Beijing Forestry University \\ No 35 Qinghua East Road, Haidian District, 100083 Beijing, China \\ ${ }^{6}$ Sorghum Research Sub-Station, Dera Ghazi Khan, Punjab, Pakistan \\ ${ }^{7}$ College of Environmental Sciences and Engineering, Beijing Forestry University, Beijing \\ 100083, China \\ ${ }^{*}$ Corresponding authors \\ e-mail: dilawarafridi333@hotmail.com,gaolushuag@bjfu.edu.cn,huago_huang@bjfu.edu.cn
}

(Received 23 $3^{\text {rd }}$ May 2019; accepted $16^{\text {th }}$ Oct 2019)

\begin{abstract}
Forests play a major role in the regional and global carbon cycle. Climate change events have become serious issue, forests from various geographical regions have different sensitivities to climate variation. Therefore, we examine the effect of annual precipitation and annual temperature from 1950-2016 of white birch (Betula platyphylla) stem biomass and composition in Daxing'anling Mountain Inner Mongolia China. We conduct a field survey, a total of 27 plots were established as the research area. In this study, we used allometric equation including the following components: diameter at breast height $(\mathrm{DBH})$ and tree height $(\mathrm{H})$. Our result showed that the response of Betula platyphylla stem biomass has a strong correlation with annual precipitation $\left(R^{2}=0.80\right)$, and with temperature $\left(R^{2}=0.75\right)$. A positive correlation was found for height with annual precipitation $\left(\mathrm{R}^{2}=0.76\right)$ and annual temperature $\left(\mathrm{R}^{2}=0.51\right)$. Additionally, a slightly positive correlation was observed for density with annual precipitation $\left(\mathrm{R}^{2}=0.26\right)$ and annual temperature $\left(\mathrm{R}^{2}=0.20\right)$. Our results also predicted that competition for survival played a significant role in tree growth. To achieve fast tree growth and high stem biomass response, systematically based forest management strategies, including thinning operation and selective cuttings could be established even under harsh Mongolian weather conditions. Our finding could suggest forest management guidelines for the normal growth of Betula platyphylla forest.
\end{abstract}

Keywords: Betula platyphylla, stem biomass, forest ecosystem, global warming, carbon stock 


\section{Introduction}

Understanding the prediction and response of forest ecosystem to climate change is a crucial challenge for scientists worldwide (Pan et al., 2013). During the last decade, most studied forest ecosystem characters are the tree biomass and carbon storage. The knowledge of the forest distribution is an essential feature for the conservation strategies, including the reduction of global warming by carbon store in forest ecosystem (Saatchi et al., 2011; Baccini et al., 2012). To study boreal forest is particularly important because they store 460 billion tons of carbon in their biomass and soil, which is equal to the total atmospheric carbon stock (Pan et al., 2011), and process 40 billion tons of carbon annually (Beer et al., 2010). Because they cover a large area of land and play an important role in global climate, regulating energy balance and evaporation at the earth. Inverse modeling of biomass and carbon sink sources from the latitudinal distribution of atmospheric carbon dioxide concentration indicates that a major terrestrial carbon sink is located in ecosystem of the northern hemisphere (Tans et al., 1990; Menon et al., 2007) and also believed that significant fraction of this carbon sink occurs in the northern boreal forest (Hyvönen et al., 2007). Boreal forests also contribute to the diversity, richness, productivity in Daxing'anling Mountain in Inner Mongolia China, which exists under a wide range of harsh environmental conditions (Fang et al., 2012). Recently, boreal forest to sequester a substantial amount of atmospheric carbon dioxide and store carbon in its biomass has focus attention from worldwide (Kasischke, 2000; Donato et al., 2011; Alongi, 2014). A recently conducted study on Larix gmelinii and Betula platyphylla suggested that stem biomass have a strong correlation with annual precipitation and maximum temperature (Khan et al., 2019).

Northern Mongolia Daxing'anling Mountains is the transaction zone between Siberian taiga and Asian steppes. This line of transaction takes place over several hundred kilometers from north to south (Walter, 1974). The climate of this region is strongly seasonal, characterized by short mild summers and long very cold winter with annual precipitation and temperature variation (Korpela et al., 2013). More than 90\% annual precipitation fall as rain during the growing season and another hand annual temperature in Mongolia increased by $2014{ }^{\circ} \mathrm{C}$ from last 70 years, which is higher than the rise of global average temperature. Precipitation almost decreases in every region at least $0.1 \mathrm{~mm} /$ year (Oyuntuya et al., 2015). Further decreasing of precipitation is expected in inner mountains (Sato et al., 2007). Current climate change, is considered the main driver of the vegetation change and observation showed that regional climatic variation has resulted in change in the natural and biological system, such as snow melting and the extension of growing season in the mid-high latitude areas (Douville, 2006; Shea et al., 2015; Rangecroft et al., 2016). Forest degradation significantly impact carbon stock (Baccini et al., 2012), and the recent climatic trend is already impacting forest biomass worldwide (Phillips et al., 2009). Recent studied describe that precipitation and temperature influence the forest ecosystem. Such as a change in temperature and precipitation is directly associated with global warming (Hidalgo-Muñoz et al., 2011; Coumou and Rahmstorf, 2012; Coumou et al., 2013; Omondi et al., 2014). During the last decades, due to the change of precipitation and temperature, many forest sites are replaced by steppe vegetation, while the composition of remaining species changes in the favor of pioneer tree species. Therefore, regeneration of different species increase their interest, while the effect the growth of the native tree species such as white birch (Betula platyphylla) (Dulamsuren et al., 2011; Khishigjargal et al., 2014; Gradel et al., 2017). Betula platyphylla growth pattern relationship with climate change is also useful for the forecast of species distribution and forest productivity (James, 2011; De Grandpré et al., 2011). 
Betula platyphylla was also known as, Manchurian birch or Asian white birch. Betula platyphylla is one of the common tree species in Daxing'anling Mountains Inner Mongolia. This species is drought sensitive, have good resistance against frost and able to grow under different climatic condition (Gradel et al., 2017). Betula platyphylla had good economic value and its height can reach up to $27 \mathrm{~m}$ along with the life duration of 140 years (Zyryanova et al., 2010). It is also one of the pioneer tree species from the south forest outposts in Inner Mongolia. Still, it is the most dominant tree species in the forest instead of human disturbance, cutting and use is a fire due to its fast sprouting capability (Otoda et al., 2013). It is important to protect this species to maintain their forest cover because of its play a significant role in biomass storage as we as in carbon sequestration potential (Hansen et al., 2013). Numerous approaches examine to understand forest biomass. Some are based on a comparison of remote sensing data with standing variables, such as diameter, height, and density to estimate aboveground biomass of trees (Baraloto et al., 2011). This type of correlative studies provide spatially explicit and to verified the estimate the above-ground biomass for an extensive assessment of carbon stock (Saatchi et al., 2011). This method has great importance for mapping carbon stock and evaluating risk from land-use change, which is beneficial for policy involvements (Asner and Mascaro, 2014).

Therefore, allowed the author to investigate the effect of climatic factors and stand characteristics of stem biomass allocation pattern of Betula platyphylla species. Although the dataset of China has used to evaluate the temperature effect on biomass allocation in the forest (Lie and Xue, 2016). While data about the effect of climatic factors on stem biomass and composition of Betula platyphylla forest is still lacking. Therefore, we want to find out the relationship between climatic factors such as precipitation and temperature from 1950-2016 with Betula platyphylla stem biomass. We also want to examine the influence of climatic factors on the height and density of Betula platyphylla.

\section{Material and methods}

\section{Study area}

Daxing'anling mountains are located at (E'7118.19.10-W'126.41.52, N'47.48.35S53.33.12) in the Heilongjiang province of China which cover the area of $83000 \mathrm{~km}^{2}$ with an altitude of $3556 \mathrm{~m}$ (Figure 1). This area has cold continental monsoon weather with an annual temperature of $2.8^{\circ} \mathrm{C}$. Annual precipitation mostly received in July to August from 350-500 mm. snow covers the land for five months in the winter season, which have depth up to $30-50 \mathrm{~cm}$ in the forest area with wind flow of 1106 miles per hours. Betula platyphylla is the dominant tree species along Dahurian larch (Larix gmelini), Scots pine (Pinus sylvestris var), Mongolian oak (mongolica) among others are common tree species. During the months of summer from April to July of each year usually occur thunderstorms, lightning fires which become a cause burning to this area.

\section{Field data collection}

To take forest data a field survey was conducted in 2017 in Daxing'anling mountain of Inner Mongolia Autonomous Region of China. We used a random sampling method and a total of 27 circular plots was taken in the study area. Each selected sampling plot have a radius of $17.84 \mathrm{~m}$. To find out stem biomass and carbon stock of Betula platyphylla stand forest, tree diameter at breast height $(\mathrm{DBH})$, tree height $(\mathrm{H})$ and Density (D) were measured in the study area. 


\section{Climatic data collection}

Climatic factors, such as annual precipitation and annual temperature from 1950 to 2016 were chosen as the parameters in the study area of Daxing'anling Mountain Inner Mongolia, China (Figure 2). Data of annual precipitation and annual temperature were download from the (0.50) grid data with help of KNMI climate Explorer [https://climexp.knmi.nl]. The climate station was uniformly distributed in northeastern Inner Mongolia China. Climatic data of each sample plot was download from its coordinate using a global positioning system (GPS) with an accuracy of 1-meter distance. It is used to extract the geographical data of each sample plot. Climate record has been assessed by China metrological administration (CMA) to assure consistency with continuity and to maintain the quality of instrument location and relocation of the stations.

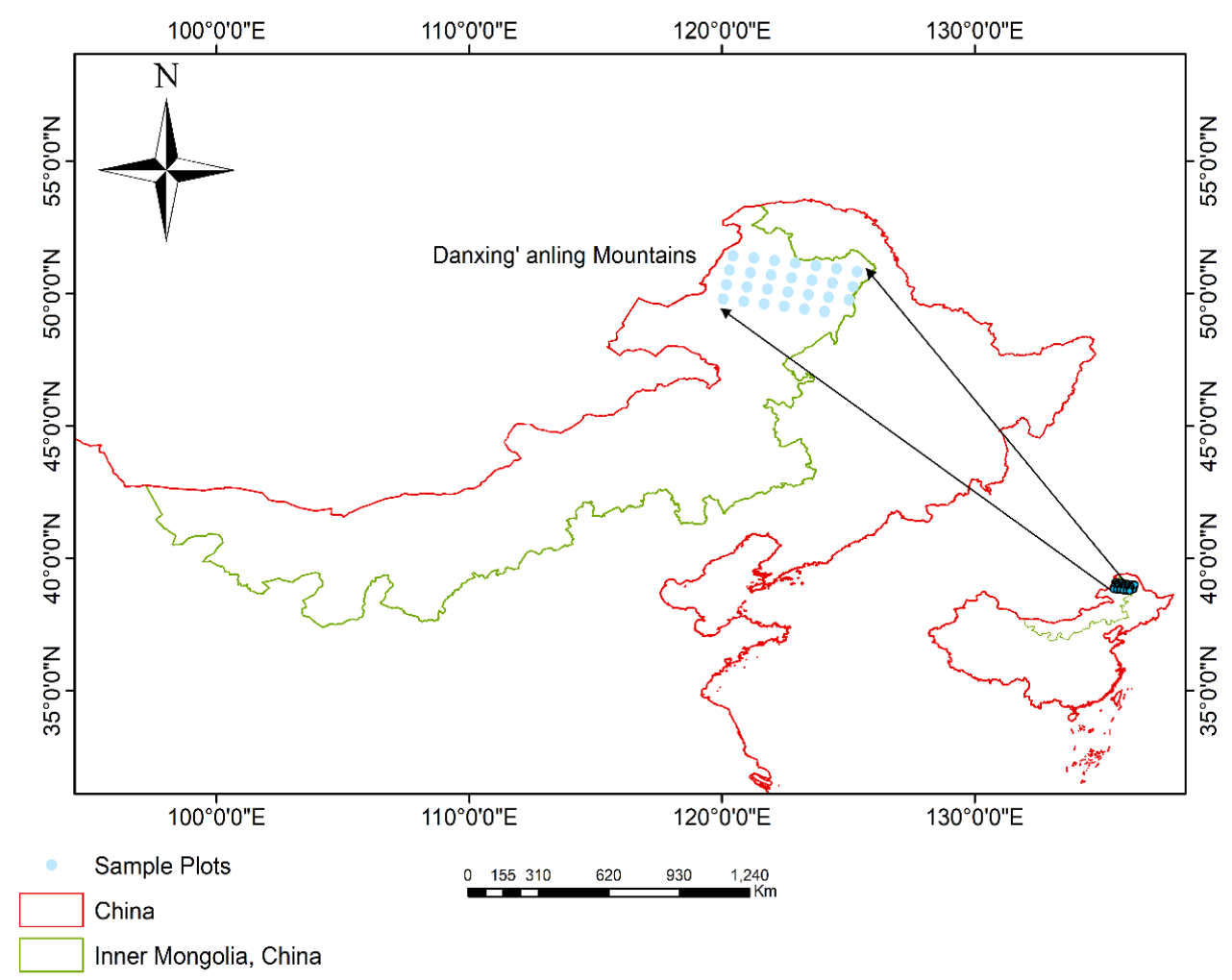

Figure 1. Geographical Mapping of the study area. Map showing the geographic location of Betula platyphylla plots in Daxing'anling Mountains Inner Mongolia, China

\section{Stem biomass estimation}

Several allometric equations have been developed by researchers to estimate biomass of different tree species using several variables as predictors or independent variables. $\mathrm{DBH}$, total height, volume, basal area, density, and crown radius are the common variables used for estimation of tree biomass (Chave et al., 2005; Mandal et al., 2013; Goodman et al., 2014). The allometric equation gives us a result of the linear and nonlinear correlation between variables in two dimensions (Picard et al., 2012). The quality of the allometric equation is necessary for ensuring the accuracy of forest biomass estimation. It is not only the matter of error but also a statistical toll during the 
process should be considered (Picard et al., 2012). Stem biomass should be measured from the recommended component such as diameter at the breast height and height of the tree $(\mathrm{H})$ (Chave et al., 2006). A model is considered reasonable if it yields estimates with minimum standard error (SEE), the minimum sum of the square of the residual error (SSE) throughout the range of data, does not give negative estimates and does not show a decrease in biomass with an increase in diameter or height (Ali et al., 2016).

The following allometric equation was used for Betula platyphylla to find out stem biomass and carbon stock which is developed by (Cheng and Li, 1989).

$$
\text { Ws }=0.1193(\mathrm{D} 2 \mathrm{H}) 0.8372
$$

To estimate the stem biomass having a coefficient of determination of $\left(\mathrm{R}^{2}\right)$ of 0.1193 . Where (Ws), is the stem biomass, tree diameter at breast height (D) and tree height $(\mathrm{H})$. To find out total stem biomass per plot was summed for all plots and average to get the mean stem biomass, which was then converted to tons per hectare. Biomass fraction analysis was used to convert the value to its carbon equivalent. Carbon stock was determined as the product of the carbon sink and corresponding biomass of the individual tree.

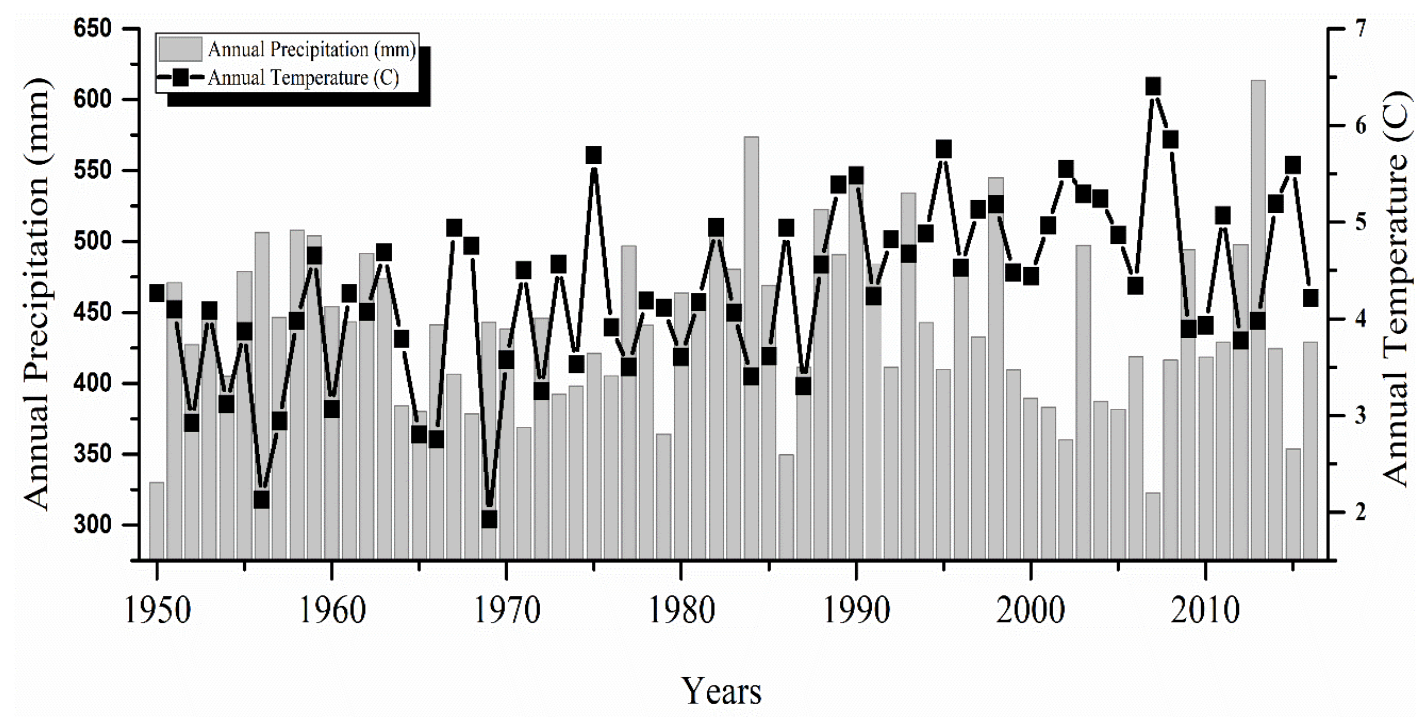

Figure 2. Yearly climate diagram. Yearly climate diagram of annual precipitation and annual temperature from 1950-2016 in Daxing'anling Mountain Inner Mongolia, China

\section{Statistical analysis}

Regression analysis was performed between dependent variables like stem biomass and carbon stock with explanatory variables like diameter, density, height and climatic variables Such as annual precipitation and annual temperature. The coefficient of determination $\left(\mathrm{R}^{2}\right)$ and probability level $(p \leq 0.05)$ was used to determine the quality of curves. To check the variables relationship accuracy, we used linear regression analysis to check the variables relationship accuracy. All statistical analysis Analyses were performed using Origin-2016. 


\section{Results}

\section{The growing stock of Betula platyphylla}

Betula platyphylla is the second most dominant species of Daxing'anling Mountains Inner Mongolia China, instead of human's disturbance, cutting and fires, due to its sprouting capability. The result revealed that average stem density ranged from $71.7 \pm 21.6\left(\right.$ trees $\mathrm{ha}^{-1}$ ) while, the total range between low to high stem density was $34.0 \pm 111.0\left(\right.$ trees $\mathrm{ha}^{-1}$ ). The mean diameter of the tree was in the range of $16.3 \pm 3.3$ $(\mathrm{cm})$ to $11.4 \pm 23.8(\mathrm{~cm})$. The value of average height ranges from $20.8 \pm 4.49(\mathrm{~m})$ to $14.0 \pm 29.0(\mathrm{~m})$, (Table 1).

Table 1. Growing stock characteristics of Betula platyphylla

\begin{tabular}{c|c|c|c|c}
\hline No & Betula platyphylla & Average density & Average diameter & Average height \\
\hline 1 & Mean \& Standard deviation & $71.7 \pm 21.6$ & $16.3 \pm 3.3$ & $20.8 \pm 4.4$ \\
2 & Minimum \& Maximum & $34.0 \pm 111.0$ & $11.4 \pm 23.8$ & $14.0 \pm 29.0$ \\
\hline
\end{tabular}

In order to study the relationship between stem biomass (ton/ha), height (m), density $\left(\mathrm{ha}^{-1}\right)$ with annual precipitation $(\mathrm{mm})$ and annual temperature $\left({ }^{0} \mathrm{C}\right)$ regression models were developed in detail which is given below in (Table 2).

Table 2. Relationship type, equation and $R^{2}$ value of the Betula platyphylla stand

\begin{tabular}{c|c|l|l|c}
\hline Climatic factor & Parameters & Relationship type & Equation & $\mathbf{R}^{2}$ Value \\
\hline & Stem biomass & Polynomial, Linear & $\mathrm{y}=-115.9592+0.6129^{*} \mathrm{x}$ & 0.8014 \\
Precipitation & Height & Polynomial, Linear & $\mathrm{y}=-21.9297+0.1015^{*} \mathrm{x}$ & 0.7674 \\
& Density & Polynomial, Linear & $\mathrm{y}=81.8608+12.4413^{*} \mathrm{x}$ & 0.0696 \\
\hline & Stem biomass & Polynomial, Linear & $\mathrm{y}=81.8608+12.4413^{*} \mathrm{x}$ & 0.7562 \\
Temperature & Height & Polynomial, Linear & $\mathrm{y}=12.4017+1.7366^{*} \mathrm{x}$ & 0.5144 \\
& Density & Polynomial, Linear & $\mathrm{y}=54.3686+3.5805^{*} \mathrm{x}$ & 0.0921 \\
\hline
\end{tabular}

Relationship of precipitation $(\mathrm{mm})$ and temperature $\left({ }^{0} \mathrm{C}\right)$ with stem biomass (ton/ha), height $(\mathrm{m})$ and density $\left(\mathrm{ha}^{-1}\right)$ of Betula platyphylla

\section{Biomass and carbon stock of Betula platyphylla with climatic factors}

Total tree biomass distribution of Betula platyphylla forest was recorded at a range of $142.2 \pm 26.2$ (ton/ha) with, variation from minimum to maximum $26.2 \pm 188.3$ (ton/ha) was absorbed. While the total average stem biomass 142 (ton/ha) were found. Carbon stock recorded at the range of $68.7 \pm 23.0$ to $23.0 \pm 134.4$ (ton/ha) with, total average carbon stock of 71 (ton/ha) in the study area. The total average precipitation $421(\mathrm{~mm})$ recorded with the range of $421.2 \pm 38.3$ along, variation from minimum to maximum $38.3 \pm 490.0 \mathrm{~mm}$. The temperature range was $4.9 \pm 1.8$ to $1.8 \pm 134.4\left({ }^{0} \mathrm{C}\right)$ with a total average temperature of $5\left({ }^{\circ} \mathrm{C}\right)$, which are given in the following (Table 3$)$.

\section{Effect of climatic factors on stem biomass, height, and density of Betula platyphylla}

To study the influence of climatic variables such as annual precipitation and annual temperature from 1950-2016 on stem biomass, height and density of Betula platyphylla in Daxing'anling Mountains Inner Mongolia. Annual precipitation and annual temperature have a positive correlation with Betula platyphylla stem biomass and height. While a negative correlation was absorbed with a density of Betula platyphylla. 
According to coefficient correlation $(\mathrm{P} \leq 0.05)$, the result showed that annual precipitation $\left(\mathrm{R}^{2}=0.80\right)$ and annual temperature $\left(\mathrm{R}^{2}=0.75\right)$ have the strongest correlation with stem biomass (Figure 3).

While, height have strong correlation with annual precipitation $\left(\mathrm{R}^{2}=0.76\right)$ and annual temperature $\left(\mathrm{R}^{2}=0.51\right)$, respectively (Figure 4$)$.

Table 3. Biomass and carbon parameters with climatic variables of Betula platyphylla

\begin{tabular}{c|c|c}
\hline Betula platyphylla & Mean \& Standard deviation & Minimum \pm Maximum \\
\hline Stem Biomass & $142.2 \pm 26.2$ & $26.2 \pm 188.3$ \\
Carbon Stock & $68.7 \pm 23.0$ & $23.0 \pm 134.4$ \\
Precipitation & $421.2 \pm 38.3$ & $38.3 \pm 490.0$ \\
Temperature & $4.9 \pm 1.8$ & $1.8 \pm 134.4$ \\
\hline
\end{tabular}
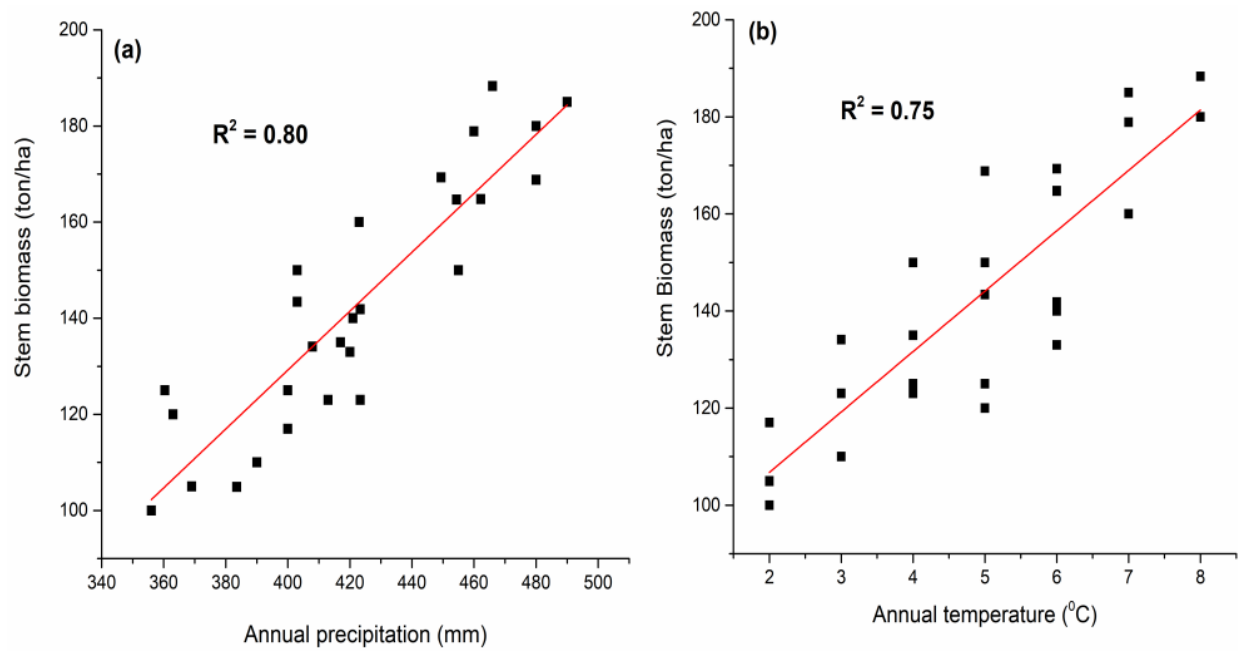

Figure 3. Stem biomass correlation with annual precipitation and temperature. Betula platyphylla stem biomass correlation with Annual precipitation (a) and Annual temperature (b) from $1950-2016$
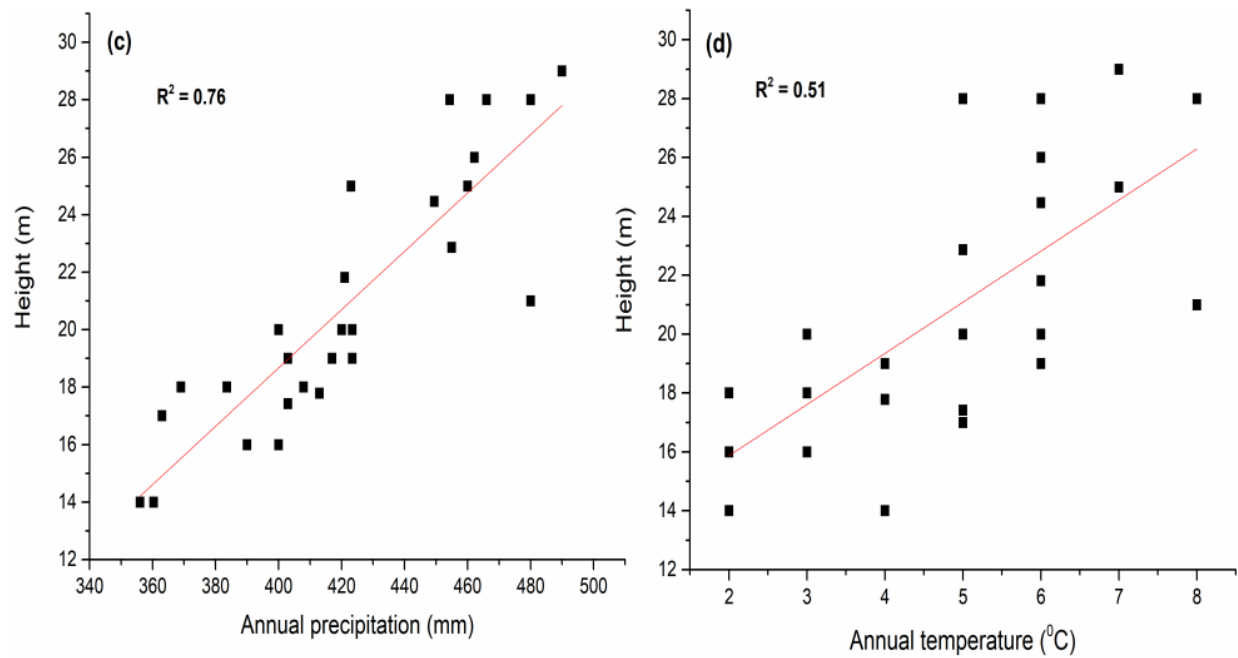

Figure 4. Height correlation with annual precipitation and temperature. Betula platyphylla height correlation with Annual precipitation (c) and Annual temperature (d) from 1950 - 2016 
In addition, slightly positive correlation was found between Betula platyphylla density with annual precipitation $\left(R^{2}=0.26\right)$ and annual temperature $\left(R^{2}=0.20\right)$ (Figure 5).
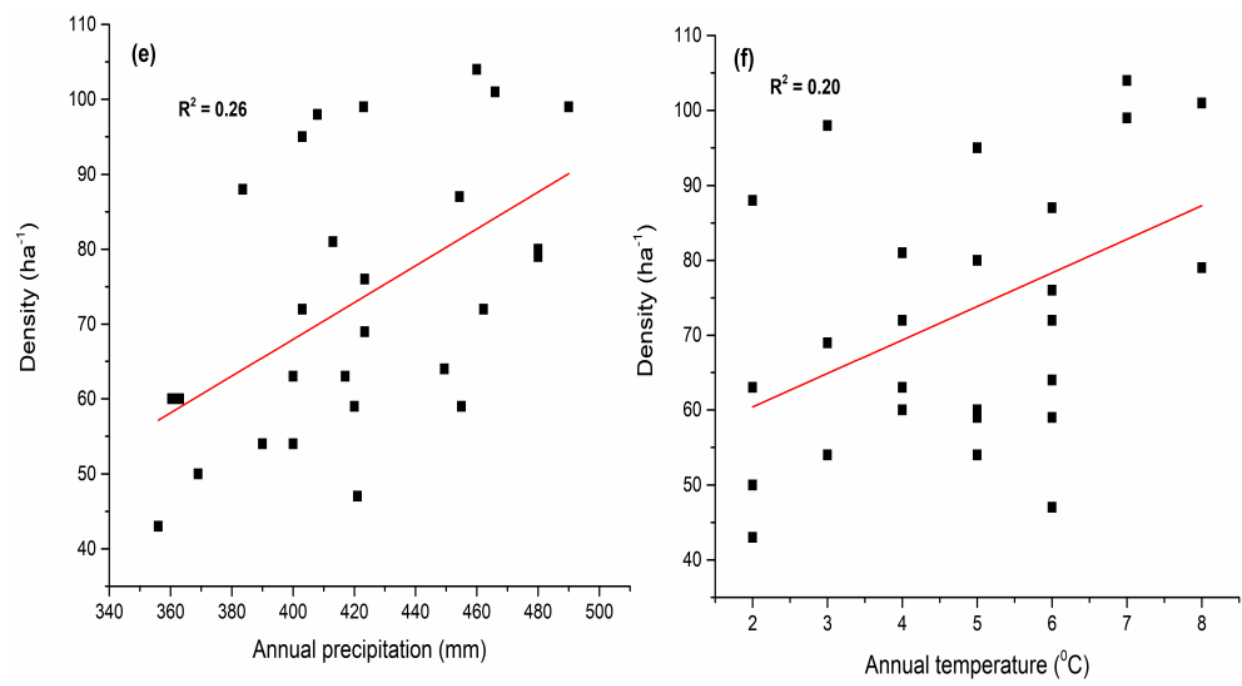

Figure 5. Density correlation with annual precipitation and temperature. Betula platyphylla density correlation with Annual precipitation (e) and Annual temperature (f) from 1950 - 2016

\section{Discussion}

Daxing'anling Mountains of Inner Mongolia is the important region of northern China. It is located at the high latitude of the northern hemisphere. Which is considered the most sensitive zone to global climate change (Dai et al., 2002; Wang et al., 2012). Betula platyphylla forest of this region plays a key role in the contribution of global carbon flux (Wang et al., 2006; Cai et al., 2015), as well as, in the establishment of forest lands consequent harvest and wildfires (Wang et al., 2015). It holds 8.39 million hectare of forest land and 0.76 billion $\mathrm{m}^{3}$ of timber stock, respectively (Fang et al., 2001; Wang et al., 2006). Wide distribution with transaction character from boreal to the temperate zone, make it important in its prime production and carbon sequestration potential (Wang et al., 2006, 2008). Boreal forests in Inner Mongolia also have tremendous carbon storage mainly due to their vast forest area and living wood stock volume, though their coverage and carbon density lag behind many other provinces in China. Thus, as a whole, they play a significant role in the Chinese terrestrial ecosystem carbon cycle and in turn play an important role in the global carbon cycle (Sun et al., 2008). Meanwhile, there are many challenges as well as opportunities for a long-time forest in the area is lack of management with the extensive degradation of existent stands and poor stand quality and low productivity. The aggravation of desertification accompanying warming and drying trend under climate change is a huge threat to the forests.

Forest vegetation under different climate conditions reacts with a different way to their climatic factors. Climatic variables assessment of the last 66 year annual precipitation and annual temperature predict positive correlation with Betula platyphylla. Betula platyphylla stem biomass has a strong correlation with annual precipitation $\left(\mathrm{R}^{2}=0.80\right)$, and annual temperature $\left(\mathrm{R}^{2}=0.75\right)$. While, positive correlation was found 
for height with annual precipitation $\left(\mathrm{R}^{2}=0.76\right)$ and annual temperature $\left(\mathrm{R}^{2}=0.51\right)$. Forests response positively to the impact of rising precipitation and temperature (Fang et al., 2003; Piao et al., 2005), and they have a positive effect on forest biomass (Lindner et al., 2010). Increase in precipitation and temperature will increase the absorption of carbon dioxide in the forest vegetation (Grant et al., 2004). In term of, stand age had an influence on forest carbon storage. Increasing of stand age also increase carbon storage capacity (Yu et al., 2017). At last, at last, the carbon storage in the forest decreases to a relatively stable level, due to the limiting of hydraulic resistance (Zaehle et al., 2006), and the growth of wood become very slow, which is almost not change (Liu et al., 2012). Some studies also predicted that precipitation and temperature are the main climatic factors that affect forest vegetation in the mid-western United States and China (Peckham et al., 2012), Russia (Alexeyev et al., 1995), Canada, and the Netherlands (Nabuurs and Mohren, 1993) among other places. While the response of vegetation types to precipitation and temperature has differed among places. The rising of precipitation and temperature have been found to increase the forest biomass in colder and wetter ecoregions (Dymond et al., 2015), but reduce the net rate of stem biomass in the Amazon rainforest (Brienen et al., 2015), and the growth rates of mature rainforests (Hopkin, 2007).

Additionally, the results showed that precipitation and temperature were significantly affected by plant density. Due to which the response of density of Betula platyphylla has a slightly positive correlation with the annual precipitation $\left(\mathrm{R}^{2}=0.035\right)$ and annual temperature $\left(\mathrm{R}^{2}=0.09\right)$, Similarly to the previous studies on tropical elevation transect forest (Leuschner et al., 2007; Girardin et al., 2010). Increase in plant density creates the interplant competition over light and precipitation which cause the disturbance in the balance of growth regulators. Under these conditions, plant density increases while, decrease in light and precipitation penetration into middle and lower layers of canopy and auxin decomposition (Imam and Ranjbar, 2000). Increase in plant density had a significant effect on Betula platyphylla plant height. Which tends to decrease because the plants compete over other growth affecting parameters than light (Mukhopadhyay and Sen, 1997).

Generally, denser Betula platyphylla stands forest results in higher total production, but the growth of the individual trees will be small (Ohtsuka et al., 2005). The increased volume production can though easily be lost through damages caused by wind or snow (Nykänen et al., 1997). With an increased number of stems density, the dimension decreases, while the volume concentrates in weaker dimensions (Coomes and Allen, 2007). The utility of wood products will be increased with lower stem densities (King et al., 2006). When pre-commercial thinning is performed competition for light and nutrition will decrease and the single stem will have the possibility to increase its diameter growth (Pothier, 2002; Karp and Shield, 2008). The main role of Betula platyphylla Silviculture is to have dense stands initially and then successively widening the spacing between the stems (Almgren, 1990). The green crown should never be smaller than half the stem length (Lapidge et al., 2000; Hörnfeldt, 2014). Since shad intolerant species like Betula platyphylla has a strong relationship between tree crown diameter and growth (Dolezal et al., 2004). Betula platyphylla stands with less than $50 \%$ of the living crown will have a small possibility to respond positively to future thinning (Dolezal et al., 2004). Thus, other stand variables such as height, diameter, and stem biomass could be important parameters to driving this observation, 
however, the data of wood density in mountain forests is infrequent and requires more sampling effort (Chave et al., 2009).

Demonstrating to find out stem biomass quantification in the Betula platyphylla forest in Daxing'anling Mountain. The destructive sampling method was not possible in our study site. That's why we attempt to minimize the uncertainty, we used the allometric equation developed in a similar climate condition with similar tree composition (Cheng and Li, 1989). In general tree diameter at the breast height and height of the tree is commonly used is a parameter to find out tree biomass in most equations (Wang, 2006; Dong et al., 2014; Wang et al., 2017). Furthermore, its depend on research goals and three components to investigate tree biomass with the help of equation (Zou et al., 2015; Kralicek et al., 2017).

Thus, during 1950-2016, the response of stem biomass and height of Betula platyphylla forest have a strong correlation with annual precipitation and annual temperature. While density has a negative correlation. That's mean, it also needs further research on forest management and the relative contribution of human activities to forest vegetation in Inner Mongolia.

\section{Conclusion}

In this study, we examined the effect climate factors, such as precipitation and temperature from 1950-2016 on Betula platyphylla forest ecosystem in Daxing'anling Mountains Northeast China. The response of Betula platyphylla to precipitation and temperature was positively correlated with stem biomass and tree height but negatively correlated with the density. Which predict that forest ecosystem also needs a proper management practice for normal growth. As we know, forests are an important component of the global carbon cycle. Betula platyphylla forest management can contribute towards emissions reductions and to carbon sequestration. To increase Betula platyphylla forest capacity regarding biomass and carbon sequestration providing incentives for the maintenance of future and existing forest resource, enhancing regeneration to increase species composition and stocks, increase people participation in forest management, decelerating hot spot for carbon sequestration and protected area.

Acknowledgements. This study was supported by grant from Key Project of National Key Research and Development Plan (2017YFC0504003-1). We are thankful to the funding agency and all people how helped us during this study.

\section{REFERENCES}

[1] Alexeyev, V., Birdsey, R., Stakanov, V., Korotkov, I. (1995): Carbon in vegetation of Russian forests: methods to estimate storage and geographical distribution. - Water, Air, and Soil Pollution 82: 271-282.

[2] Ali, A., Iftikhar, M., Ahmad, S. N., Muhammad, S., Khan, A. A. (2016): Development of allometric equation for biomass estimation of Cedrus deodara in dry temperate forests of Northern Pakistan. - Journal of Biodiversity and Environmental Sciences 9: 43-50.

[3] Almgren, G. (1990): Lövskog: björk, asp och al i skogsbruk och naturvård: Skogsstyr.

[4] Alongi, D. M. (2014): Carbon cycling and storage in mangrove forests. - Annual review of marine science 6: 195-219. 
[5] Asner, G. P., Mascaro, J. (2014): Mapping tropical forest carbon: Calibrating plot estimates to a simple LiDAR metric. - Remote Sensing of Environment 140: 614-624.

[6] Baccini, A., Goetz, S. J., Walker, W. S., Laporte, N. T., Sun, M., Sulla-Menashe, D., Hackler, J., Beck, P. S. A., Dubayah, R., Friedl, M. A., Samanta, S., Houghton, R. A. (2012): Estimated carbon dioxide emissions from tropical deforestation improved by carbon-density maps. - Nature climate change 2: 182-185.

[7] Baraloto, C., Rabaud, S., Molto, Q., Blanc, L., Fortunel, C., Hérault, B., Dávila, N., Mesones, I., Rios, M., Valderrama, E. Fine, P. V. A. (2011): Disentangling stand and environmental correlates of aboveground biomass in Amazonian forests. - Global change biology 17: 2677-2688.

[8] Beer, C., Reichstein, M., Tomelleri, E., Ciais, P., Jung, M., Carvalhais, N., Rödenbeck, C. (2010): Terrestrial gross carbon dioxide uptake: global distribution and covariation with climate. - Science: 1184984.

[9] Brienen, R. J. W., Phillips, O. L., Feldpausch, T. R., Gloor, E., Baker, T. R. (2015): Long-term decline of the Amazon carbon sink. - Nature 519: 344-348.

[10] Cai, H., Di, X., Chang, S. X., Wang, C. K., Shi, B., Geng, P. F., Jin, G. Z. (2015): Carbon storage, net primary production, and net ecosystem production in four major temperate forest types in northeastern China. - Canadian Journal of Forest Research 46: 143-151.

[11] Chave, Jr., Andalo, C., Brown, S., Cairns, M. A., Chambers, J. Q., Eamus, D., Fölster, H., Fromard, F., Higuchi, N., Kira, T., Lescure, J.-P., Nelson, B. W., Ogawa, H., Puig, H., Riéra, B., Yamakura, T. (2005): Tree allometry and improved estimation of carbon stocks and balance in tropical forests. - Oecologia 145: 87-99.

[12] Chave, J., Muller-Landau, H. C., Baker, T. R., Easdale, T. A., Steege, H., Webb, C. O. (2006): Regional and phylogenetic variation of wood density across 2456 neotropical tree species. - Ecological applications 16: 2356-2367.

[13] Chave, J., Coomes, D., Jansen, S., Lewis, S. L., Swenson, N. G., Zanne, A. E. (2009): Towards a worldwide wood economics spectrum. - Ecology letters 12: 351-366.

[14] Cheng, Y. X., Li, Z. X. (1989): A study on biomass of three main forest types in Larix gmelinii forest. - Inner Mongolia Forestry Investigation and Design 4: 89-100.

[15] Coomes, D. A., Allen, R. B. (2007): Mortality and tree-size distributions in natural mixed-age forests. - Journal of Ecology 95: 27-40.

[16] Coumou, D., Rahmstorf, S. (2012): A decade of weather extremes. - Nature Climate Change 2: 491-496. Nature Publishing Group. doi.

[17] Coumou, D., Robinson, A., Rahmstorf, S. (2013): Global increase in record-breaking monthly-mean temperatures. - Climatic Change 118: 771-782.

[18] Dai, L., Wu, G., Zhao, J., Kong, H. M., Shao, G. F., Deng, H. B. (2002): Carbon cycling of alpine tundra ecosystems on Changbai Mountain and its comparison with arctic tundra. - Science in China Series D: Earth Sciences 45: 903.

[19] De Grandpré, L., Tardif, J. C., Hessl, A., Pederson, N., Conciatori, F., Green, T. R., Oyunsanaa, B., Baatarbileg, N. (2011): Seasonal shift in the climate responses of Pinus sibirica, Pinus sylvestris, and Larix sibirica trees from semi-arid, north-central Mongolia. - Canadian Journal of Forest Research 41: 1242-1255.

[20] Dolezal, J., Ishii, H., Vetrova, V. P., Sumida, A., Hara, T. (2004): Tree growth and competition in a Betula platyphylla-Larix cajanderi post-fire forest in central Kamchatka. - Annals of Botany 94: 333-343.

[21] Donato, D. C., Kauffman, J. B., Murdiyarso, D., Kurnianto, S., Stidham, M., Kanninen, M. (2011): Mangroves among the most carbon-rich forests in the tropics. - Nature geoscience 4: 293.

[22] Dong, L., Zhang, L., Li, F. (2014): A compatible system of biomass equations for three conifer species in Northeast, China. - Forest Ecology and Management 329: 306-317.

[23] Douville, H. (2006): Impact of regional SST anomalies on the Indian monsoon response to global warming in the CNRM climate model. - Journal of climate 19: 2008-2024. 
[24] Dulamsuren, C., Hauck, M., Leuschner, H. H., Leuschner, C. (2011): Climate response of tree-ring width in Larix sibirica growing in the drought-stressed forest-steppe ecotone of northern Mongolia. - Annals of Forest Science 68: 275-282.

[25] Dymond, C. C., Beukema, S., Nitschke, C. R., Coates, K. D., Scheller, R. M. (2015): Carbon sequestration in managed temperate coniferous forests under climate change. Biogeosciences Discussions 12.

[26] Fang, J., Chen, A., Peng, C., Zhao, S., Ci, L. (2001): Changes in forest biomass carbon storage in China between 1949 and 1998. - Science 292: 2320-2322.

[27] Fang, J., Piao, S., Field, C. B., Pan, Y., Guo, Q., Zhou, L., Peng, C., Tao, S. (2003): Increasing net primary production in China from 1982 to 1999. - Frontiers in Ecology and the Environment 1: 293-297.

[28] Fang, J., Shen, Z., Tang, Z., Wang, X., Wang, Z., Feng, J., Liu, Y., Qiao, X., Wu, X., Zheng, C. (2012): Forest community survey and the structural characteristics of forests in China. - Ecography 35: 1059-1071.

[29] Girardin, C. A. J., Malhi, Y., Aragao, L., Mamani, M., Huaraca Huasco, W., Durand, L., Feeley, K. J., Rapp, J., Silva-Espejo, J. E., Silman, M., Salinas, N., Whittaker, R. J. (2010): Net primary productivity allocation and cycling of carbon along a tropical forest elevational transect in the Peruvian Andes. - Global change biology 16: 3176-3192.

[30] Goodman, R. C., Phillips, O. L., Baker, T. R. (2014): The importance of crown dimensions to improve tropical tree biomass estimates. - Ecological applications 24: 680698.

[31] Gradel, A., Haensch, C., Ganbaatar, B., Dovdondemberei, B., Nadaldorj, O., Günther, B. (2017): Response of white birch (Betula platyphylla Sukaczev) to temperature and precipitation in the mountain forest steppe and taiga of northern Mongolia. Dendrochronologia 41: 24-33.

[32] Grant, R. F., Arain, A., Arora, V., Barr, A., Black, T. A., Chen, J., Wang, S., Yuan, F., Zhang, Y. (2004): Modelling temperature effects on CO2 and energy exchange in temperate and boreal coniferous forests. - AGU Spring Meeting Abstracts.

[33] Hansen, M. C., Potapov, P. V., Moore, R., Hancher, M., Turubanova, S. A., Tyukavina, A., Thau, D., Stehman, S. V., Goetz, S. J., Loveland, T. R., Kommareddy, A., Egorov, A., Chini, L., Justice, C. O., Townshend, J. R. G. (2013): High-resolution global maps of 21 st-century forest cover change. - Science 342: 850-853.

[34] Hidalgo-Muñoz, J., Argüeso, D., Gámiz-Fortis, S., Esteban-Parra, M. J., Castro-Díez, Y. (2011): Trends of extreme precipitation and associated synoptic patterns over the southern Iberian Peninsula. - Journal of Hydrology 409: 497-511.

[35] Hopkin, M. (2007): Rising temperatures "will stunt rainforest growth". - Nature 659.

[36] Hörnfeldt, R. (2014): Silviculture adapted to multiple goals in Swedish small scale forestry. - Acta Universitatis Agriculturae Sueciae: 1652-6880; 2014:42.

[37] Hyvönen, R., Ågren, G. I., Linder, S., Persson, T., Cotrufo, M. F., Ekblad, A., Freeman, M., Grelle, A., Janssens, I. A., Jarvis, P. G., Kellomäki, S., Lindroth, A., Loustau, D., Lundmark, T., Norby, R. J., Oren, R., Pilegaard, K., Ryan, M. G., Sigurdsson, B. D., Strömgren, M., van Oijen, M., Wallin, G. (2007): The likely impact of elevated [CO2], nitrogen deposition, increased temperature and management on carbon sequestration in temperate and boreal forest ecosystems: a literature review. - New Phytologist 173: 463480.

[38] Imam, Y., Ranjbar, G. (2000): Effect of plant density and drought stress at vegetative growth stage on yield, yield components and water use efficiency in grain corn. - Iranian Journal of Agricultural Researches 2: 118-129.

[39] James, T. M. (2011): Temperature sensitivity and recruitment dynamics of Siberian larch (Larix sibirica) and Siberian spruce (Picea obovata) in northern Mongolia's boreal forest. - Forest Ecology and Management 262: 629-636.

[40] Karp, A., Shield, I. (2008): Bioenergy from plants and the sustainable yield challenge. New Phytologist 179: 15-32. 
[41] Khan, D., Muneer, M. A., Nisa, Z. U., Shah, S., Amir, M., Saeed, S., Uddin, S., Munir, M. Z., Gao, L., Huang, H. (2019): Effect of Climatic Factors on Stem Biomass and Carbon Stock of Larix gmelinii and Betula platyphylla in Daxing'anling Mountain of Inner Mongolia, China. - Advances in Meteorology, 2019.

[42] Kasischke, E. S. (2000): Boreal ecosystems in the global carbon cycle. - Fire, climate change, and carbon cycling in the boreal forest (Springer): 19-30.

[43] Khishigjargal, M., Dulamsuren, C., Leuschner, H. H., Leuschner, C., Hauck, M. (2014): Climate effects on inter-and intra-annual larch stemwood anomalies in the Mongolian forest-steppe. - Acta oecologica 55: 113-121.

[44] King, D. A., Davies, S. J., Tan, S., Md. Noor, N. S. (2006): The role of wood density and stem support costs in the growth and mortality of tropical trees. - Journal of Ecology 94: 670-680.

[45] Korpela, K., Delgado, M., Henttonen, H., Korpimäki, E., Koskela, E., Ovaskainen, O., Pietiäinen, H., Sundell, J., Yoccoz, N. G., Huitu, O. (2013): Nonlinear effects of climate on boreal rodent dynamics: mild winters do not negate high-amplitude cycles. - Global Change Biology 19: 697-710.

[46] Kralicek, K., Huy, B., Poudel, K. P., Temesgen, H., Salas, C. (2017): Simultaneous estimation of above-and below-ground biomass in tropical forests of Viet Nam. - Forest Ecology and Management 390: 147-156.

[47] Lapidge, M., Godden, M., Keynes, S. (2000): Anglo-Saxon England. - Cambridge University Press.

[48] Leuschner, C., Moser, G., Bertsch, C., Röderstein, M., Hertel, D. (2007): Large altitudinal increase in tree root/shoot ratio in tropical mountain forests of Ecuador. Basic and Applied Ecology 8: 219-230.

[49] Lie, G., Xue, L. (2016): Biomass allocation patterns in forests growing different climatic zones of China. - Trees 30: 639-646.

[50] Lindner, M., Maroschek, M., Netherer, S., Netherer, S., Kremer, A., Barbati, A., GarciaGonzalo, J., Seidl, R., Delzon, S., Corona, P., Kolström, M., Lexer, M. J., Marchetti, M. (2010): Climate change impacts, adaptive capacity, and vulnerability of European forest ecosystems. - Forest Ecology and Management 259: 698-709.

[51] Liu, Y. C., Yu, G. R., Wang, Q. F., Zhang, Y. J. (2012): Huge carbon sequestration potential in global forests. - Journal of Resources and Ecology 3: 193-201.

[52] Mandal, R. A., Yadav, B. K. V., Yadav, K. K., Dutta, I. C., Haque, S. M. (2013): Development of allometric equation for biomass estimation of eucalyptus camaldulensis: a study from Sagarnath Forest, Nepal. - Int J Biodiv Ecosyst 1: 1-7.

[53] Menon, S., Denman, K. L., Brasseur, G. (2007): Couplings between changes in the climate system and biogeochemistry. - Lawrence Berkeley National Lab. (LBNL), Berkeley, CA (United States).

[54] Mukhopadhyay, D., Sen, S. (1997): Augmentation of growth variables and yield components of plants yielding spices by foliar application of diazotrophic bacteria. Indian Journal of Agricultural Research 31: 1-9.

[55] Nabuurs, G., Mohren, G. (1993): Carbon in Dutch forest ecosystems. - NJAS wageningen journal of life sciences 41: 309-326.

[56] Nykänen, M.-L., Peltola, H., Quine, C. P., Kellomäki, S., Broadgate, M. (1997): Factors affecting snow damage of trees with particular reference to European conditions. - Silva Fennica 31(2): 193-213.

[57] Ohtsuka, T., Akiyama, T., Hashimoto, Y., Inatomi, M., Sakai, T., Jia, S., Mo, W., Tsuda, S., Koizumi, H. (2005): Biometric based estimates of net primary production (NPP) in a cool-temperate deciduous forest stand beneath a flux tower. - Agricultural and Forest Meteorology 134: 27-38.

[58] Omondi, P. A., Awange, J. L., Forootan, E., Ogallo, L., Barakiza, R., Girmaw, G. B., Fesseha, I., Kululetera, V., Kilembe, C., Mbati, M. M., Kilavi, M., King'uyu, S. M., Omeny, P., Njogu, A. K., Badr, E. M., Musa, T. A., Muchiri, P., Bamanya, D., 
Komutungaet, E. (2014): Changes in temperature and precipitation extremes over the Greater Horn of Africa region from 1961 to 2010. - International Journal of Climatology 34: 1262-1277.

[59] Otoda, T., Sakamoto, K., Hirobe, M., Undarmaa, J., Yoshikawa, K. (2013): Influences of anthropogenic disturbances on the dynamics of white birch (Betula platyphylla) forests at the southern boundary of the Mongolian forest-steppe. - Journal of forest research 18: 8292.

[60] Oyuntuya, S., Dorj, B., Shurentsetseg, B. (2015): Agrometeorological information for the adaptation to climate change. Почвы степных и лесостепных экосистем Внутренней Азии и проблемы их рационального использования: 135-140.

[61] Pan, Y., Birdsey, R. A., Fang, J., Houghton, R., Kauppi, P. E., Kurz, W. A., Phillips, O. L., Shvidenko, A., Lewis, S. L., Canadell, J. G., Ciais, P., Jackson, R. B., Pacala, S. W., McGuire, A. D., Piao, S., Rautiainen, A., Sitch, S., Hayes, D. (2011): A large and persistent carbon sink in the world's forests. - Science: 1201609.

[62] Pan, Y., Birdsey, R. A., Phillips, O. L., et al. (2013): The structure, distribution, and biomass of the world's forests. - Annual Review of Ecology, Evolution, and Systematics 44: 593-622.

[63] Peckham, S. D., Gower, S. T., Buongiorno, J. (2012): Estimating the carbon budget and maximizing future carbon uptake for a temperate forest region in the US. - Carbon balance and management 7: 6 .

[64] Phillips, O. L., Aragão, L. E., Lewis, S. L., et al. (2009): Drought sensitivity of the Amazon rainforest. - Science 323: 1344-1347.

[65] Piao, S., Fang, J., Zhou, L., Zhu, B., Tan, K., Tao, S. (2005): Changes in vegetation net primary productivity from 1982 to 1999 in China. - Global Biogeochemical Cycles 19.

[66] Picard, N., Saint André, L., Henry, M. (2012): Manual for building tree allometric equations: from the field to the prediction. - Food and Agriculture Organization of the United Nations, Centre de Coopération Internationale en Recherche Agronomique, Rome.

[67] Pothier, D. (2002): Twenty-year results of precommercial thinning in a balsam fir stand. Forest Ecology and Management 168: 177-186.

[68] Rangecroft, S., Suggitt, A. J., Anderson, K., Harrison, S. (2016): Future climate warming and changes to mountain permafrost in the Bolivian Andes. - Climatic Change 137: 231243.

[69] Saatchi, S. S., Harris, N. L., Brown, S., Lefsky, M., Mitchard, E. T. A., Salas, W., Zutta, B. R., Buermann, W., Lewis, S. L., Hagen, S., Petrova, S., White, L., Silman, M., Morel, A. (2011): Benchmark map of forest carbon stocks in tropical regions across three continents. - Proceedings of the National Academy of Sciences 108: 9899-9904.

[70] Sato, T., Kimura, F., Kitoh, A. (2007): Projection of global warming onto regional precipitation over Mongolia using a regional climate model. - Journal of Hydrology 333: 144-154.

[71] Shea, J. M., Immerzeel, W., Wagnon, P., Vincent, C., Bajracharya, S. (2015): Modelling glacier change in the Everest region, Nepal Himalaya. - The Cryosphere 9: 1105-1128.

[72] Sun, C., Chen, L., Chen, L., Han, L., Bass, S. (2008): Global Forest Product Chains. www.iisd.org.

[73] Tans, P. P., Fung, I. Y., Takahashi, T. (1990): Observational contrains on the global atmospheric CO2 budget. - Science 247: 1431-1438.

[74] Walter, H. (1974): The vegetation of Eastern Europe, Northern Asia and Central Asia. Regional vegetation monographs, Vol. VII. The vegetation of Eastern Europe, Northern Asia and Central Asia. Regional vegetation monographs, Vol. VII.

[75] Wang, C. (2006): Biomass allometric equations for 10 co-occurring tree species in Chinese temperate forests. - Forest Ecology and Management 222: 9-16.

[76] Wang, X., Fang, J., Tang, Z., Zhu, B. (2006): Climatic control of primary forest structure and DBH-height allometry in Northeast China. - Forest Ecology and Management 234: 264-274. 
[77] Wang, H.-m., Saigusa, N., Zu, Y.-g., Wang, W.-j., Yamamoto, S., Kondo, H. (2008): Carbon fluxes and their response to environmental variables in a Dahurian larch forest ecosystem in northeast China. - Journal of forestry research 19: 1-10.

[78] Wang, H., Wang, W., Qiu, L., Su, D. X. (2012): Differences in biomass, litter layer mass and SOC storage changing with tree growth in Larix gmelinii plantations in Northeast China. - Acta Ecol. Sin 32: 833-843.

[79] Wang, X., Weng, Y., Liu, G., Krasowski, M. J., Yang, C. P. (2015): Variations in carbon concentration, sequestration and partitioning among Betula platyphylla provenances. Forest Ecology and Management 358: 344-352.

[80] Wang, X., Bi, H., Ximenes, F., Ramos, J., Li, Y. (2017): Product and residue biomass equations for individual trees in rotation age Pinus radiata stands under three thinning regimes in New South Wales, Australia. - Forests 8: 439.

[81] Yu, Y., Chen, J. M., Yang, X., Fan, W., Li, M., He, L. (2017): Influence of site index on the relationship between forest net primary productivity and stand age. - PloS one 12: e0177084.

[82] Zaehle, S., Sitch, S., Prentice, I. C., Liski, J., Cramer, W., Erhard, M., Hickler, T., Smith, B. (2006): The importance of age-related decline in forest NPP for modeling regional carbon balances. - Ecological applications 16: 1555-1574.

[83] Zou, W.-T., Zeng, W.-S., Zhang, L.-J., Zeng, M. (2015): Modeling crown biomass for four pine species in China. - Forests 6: 433-449.

[84] Zyryanova, O. A., Terazawa, M., Koike, T., Zyryanov, V. I. (2010): White birch trees as resource species of Russia: their distribution, ecophysiological features, multiple utilizations. - Eurasian Journal of Forest Research 13: 25-40. 